\title{
The relationships of Cuspicephalus scarfi Martill and Etches, 2013 and Normannognathus wellnhoferi Buffetaut et al., 1998 to other monofenestratan pterosaurs
}

\author{
Mark P. Witton ${ }^{1,2}$, Michael O'Sullivan' ${ }^{1}$, David M. Martill ${ }^{1}$ \\ ${ }^{1}$ School of Earth and Environmental Sciences, University of Portsmouth, Burnaby Building, Burnaby Road, Portsmouth, \\ POI 3QL, UK \\ ${ }^{2}$ E-mail: mark.witton@port.ac.uk
}

Key words: Cuspicephalus scarfi, Jurassic, Monofenestrata, Normannognathus wellnhoferi, Pterosauria, Wukongopteridae

\begin{abstract}
The evolution of pterodactyloid pterosaurs occurred in a 'modular' fashion with 'pterodactyloid'-type crania and cervical vertebrae evolving in pterodactyloid sister taxa - early monofenestratan pterosaurs - before later postcervical modifications marked the development of the true pterodactyloid condition. This means of evolution creates problems for distinguishing isolated pterodactyloid crania from those of non-pterodactyloid monofenestratans, and has led to uncertainty over the affinities of two Late Jurassic European pterosaurs known only from skulls, Cuspicephalus scarfi Martill and Etches, 2013 and Normannognathus wellnhoferi Buffetaut et al., 1998. Some aspects of their cranial anatomy suggest affinities to early pterodactyloids - specifically the Germanodactylidae - while others indicate a relationship with a group of non-pterodactyloid monofenestratans, the Wukongopteridae. Here, we characterise the skulls of Jurassic monofenestratans to provide greater insight into the identity of these pterosaurs. We find a suite of characters indicating that Cuspicephalus is a wukongopterid, notable for being a particularly large and long snouted member of the group, as well as the youngest, and the first European record of this clade. The affinities of Normannognathus are less clear however. We consider its previous allocation to the Germanodactylidae doubtful, and note some similarities it shares with ctenochasmatoid pterodactyloids, but the only known specimen is probably too fragmentary for confident referral to any specific clade within Monofenestrata.
\end{abstract}

\section{Contents}

Introduction 115

Europe's possible non-pterodactyloid

monofenestratans

Institutional abbreviations ............................................... 118

Material and methods ............................................................ 119

Systematic declaration ……………………...................... 119

Comparative anatomy ...................................................... 119

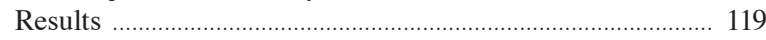

Cranial characteristics of the Wukongopteridae ........... 119

Cranial characteristics of the 'Painten

pro-pterodactyloid'

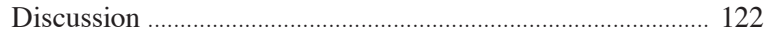

Cuspicephalus scarfi ........................................................... 122

Normannognathus wellnhoferi .......................................... 123

Significance of Cuspicephalus scarfi interpreted

as a wukongopterid ............................................................ 125

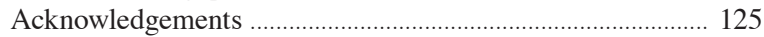

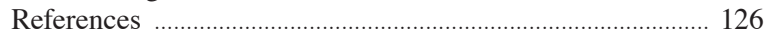

\section{Introduction}

The origin of the Pterodactyloidea is currently a hot topic in pterosaur research. Whereas a clear morphological divide once separated pterodactyloids from other pterosaurs, new discoveries have revealed major stages of their early evolution. These include the purported earliest known member of the Pterodactyloidea (Andres et al., 2014) and 'transitional' taxa bridging pterodactyloid-like anatomy to earlier pterosaurs (Lü et al., 2010; Tischlinger and Frey, 2014). Perhaps the most significant of these 'transitional' species is the Callovian-Oxfordian Tiaojishan Formation species Darwinopterus modularis Lü et al., 2010, a small pterosaur with anatomy 'intermediate' between that of pterodactyloids and their historically recognised sister group, the Rhamphorhynchidae (Lü et al., 2010). The anatomy of Darwinopterus is noted for its 'modular' nature, combining 'pterodactyloid-grade' head and neck anatomy with non-pterodactyloid postcervical features (Lü et al., 2010). Darwinopterus and the Pterodactyloidea appear to form a monophyletic clade, the Monofenestrata, named after the combined nasal and antorbital opening common to all members of this group (Lü et al., 2010). Another recent discovery, a privately-owned complete skeleton from the latest Kimmeridgian Painten Formation of Germany, apparently represents a grade of monofenestratan between Darwinopterus and the 
Pterodactyloidea (Tischlinger and Frey, 2014). As in Darwinopterus, its skull and neck possesses typical 'pterodactyloid' features while its postcranial skeleton, despite being relatively pterodactyloid-like, retains clear hallmarks of an earlier pterosaur bauplan. This specimen has not been named because of its lack of public accession and, following Tischlinger and Frey (2014), is hereafter referred to as the 'Painten Pro-pterodactyloid'.

Since Darwinopterus was described, a number of similar taxa have been identified from the Tiaojishan Formation. These include two other Darwinopterus species, D. robustodens Lü et al., 2011a and D. linglongtaensis Wang et al., 2010; as well as Kunpengopterus sinensis Wang et al., 2010, Wukongopterus lii Wang et al., 2009 and Changchengopterus pani Lü, 2009. These taxa are considered to form a clade, the Wukongopteridae (Wang et al., 2010), diagnosed by their combination of relatively derived pterodactyloid-like skulls and cervical vertebrae with more plesiomorphic, non-pterodactyloid-like postcervical anatomy (Wang et al., 2010, Hone, 2012; Andres et al., 2014). The purported early istiodactylid Archaeoistiodactylus linglongtaensis Lü and Fucha, 2010 is also probably a wukongopterid (Martill and Etches, 2010; Witton, 2013) or a close relative of this group (Sullivan et al., 2014). It is highly likely that the Tiaojishan wukongopterids are oversplit (Lü et al., 2012; Witton, 2013).

The characterisation of non-pterodactyloid monofenestratans has solely used relatively complete skeletons unambiguously demonstrating their distinctive, 'modular' anatomy. Problems arise when applying these means of identifying wukongopterids to more fragmentary Jurassic pterosaur material, however. Non-pterodactyloid monofenestratan skeletons are distinctive, but their individual 'modules' are not strongly apomorphic, instead showing plesiomorphic anatomies which are very simi-
A

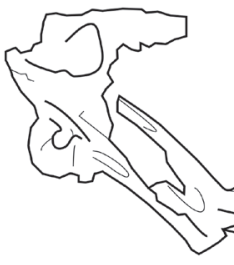

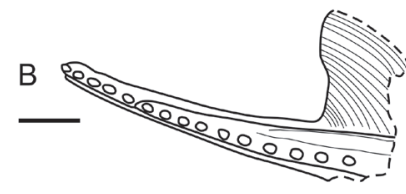

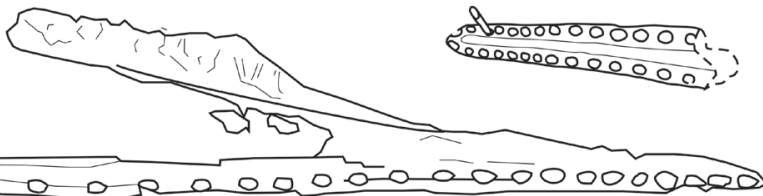

Fig. 1. A, MJML K1918, holotype skull of the long-snouted pterosaur Cuspicephalus scarfi Martill and Etches, 2013; B, MGCL 59'583, holotype of Normannognathus wellnhoferi Buffetaut et al., 1998. Scale bars represent $50 \mathrm{~mm}$ (A) and $10 \mathrm{~mm}$ (B).

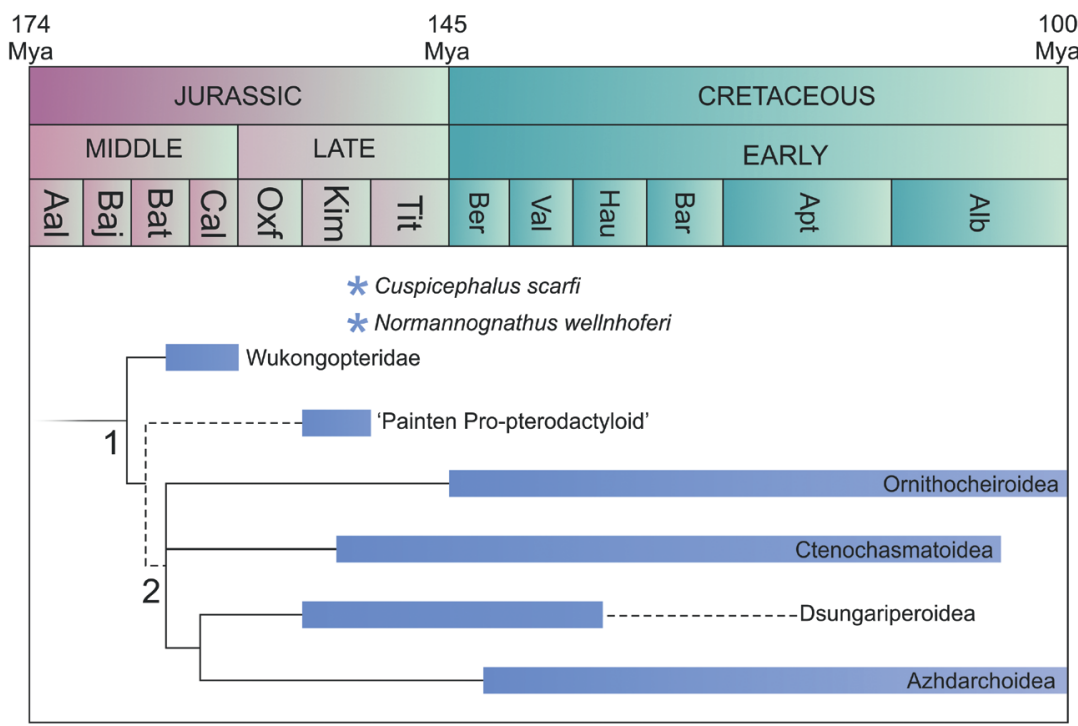

Fig. 2. Simplified stratigraphic distribution of Monofenestratan groups at the Jurassic/ Cretaceous boundary, and the stratigraphic position of the two species discussed herein, Normannognathus wellnhoferi and Cuspicephalus scarfi. Phylogeny largely based on Lü et al. (2010, 2012), but the position of the 'Painten Pro-pterodactyloid' is inferred from recent work by Tischlinger and Frey (2014). 1, Monofenestrata; 2, Pterodactyloidea. Abbreviations of geologic ages: Aal, Aalenian; Alb, Albian; Apt, Aptian; Bar, Barremian; Baj, Bajocian; Bat, Bathonian; Ber, Berriasian; Cal, Callovian; Hau, Hauterivian; Kim, Kimmeridgian; Oxf, Oxfordian; Tit; Tithonian; Val, Valanginian. 
lar to those of other Jurassic pterosaur clades. This raises questions over how precisely incomplete monofenestratan fossils can be classified if evidence of a combined pterodactyloid/non-pterodactyloid bauplan is absent: do they represent wukongopterids, pterodactyloids, or something else entirely? Lü et al. (2010) validated this concern when performing separate cladistic analyses of the cranial and cervical, and postcervical anatomy of Darwinopterus modularis. The head and neck 'modules' were found to nest deeply within the Pterodactyloidea while the postcervical module plotted as the sister taxon to the Rhamphorhynchidae (Lü et al., 2010). This problem has also been borne out in other studies where classifying isolated monofenestratan crania has proved challenging (Martill and Etches, 2013; also see below). The current diagnosis of Wukongopteridae, suggested by Wang et al. (2010), is of little help here because it is reliant on characteristics of relatively complete specimens. Most wukongopterid cranial characters provided by Wang et al. (2010) are plesiomorphic for the Monofenestrata ("confluent naris and antorbital fenestra; maxillary ramus of the jugal long, anteriorly projected and splint-like; free lateral nasal process'), and thus are of little significance without associated 'nonpterodactyloid'-like postcrania. Other suggested cranial characters may be of questionable application to the group ('quadrate inclined backwards for about $120^{\circ}$ '; see Martill and Etches [2013] for contrasting measurements). Wukongopterid postcranial characters, relating to neck and forelimb bone length ratios, may be synapomorphic (Wang et al., 2010; Sullivan et al., 2014, but require associations of several bones for their application. With the majority of the Jurassic pterosaur record comprising isolated and fragmented material (e.g. Unwin, 1996; Barrett et al., 2008), there is a clear need for greater characterisation of early monofenestratan anatomy to ensure an accurate understanding of Jurassic pterosaur diversity.

\section{Europe's possible non-pterodactyloid monofenestratans}

Three fragmentary pterosaur specimens have been identified as possible non-pterodactyloid monofenestratans, and all are from Europe (Steel, 2010; Andres et al., 2011a, b; Martill and Etches, 2013; Witton, 2013; Tischlinger and Frey, 2014). Each is represented only by cranial remains. They include NHMUK R 464, a fragmentary skull from the Bathonian Taynton Limestone Formation (the 'Stonesfield Slate') of Oxfordshire (Steel et al., 2010; Andres et al., 2011a, b). A full appraisal of NHMUK R 464 has yet to be published but is currently underway
(Andres pers. comm.), and we accordingly await publication of this before discussing this specimen further.

MJML K1918, the holotype of the long-snouted pterosaur Cuspicephalus scarfi Martill and Etches, 2013 from the Kimmeridgian Kimmeridge Clay of Dorset, UK (Fig. 1A) represents a second possible non-pterodactyloid monofenestratan. Known from a nearly complete skull, Martill and Etches (2013) noted some similarities in cranial and dental features between MJML K1918 and the wukongopterid Darwinopterus, but concluded that 'a close relationship cannot be proved' (Martill and Etches, 2013: p. 285). This was in part because the specimen also bears several similarities to the pterodactyloid Germanodactylus (Martill and Etches, 2013: p. 291), suggesting possible affinities to a more derived monofenestratan clade. The significance of Cuspicephalus potentially being related to Germanodactylus is confused by the taxonomic controversies surrounding the latter. Germanodactylus has been argued as belonging to two different pterodactyloid lineages, Archaeopterodactyloidea (sensu Kellner, 2003) or Dsungaripteroidea (sensu Unwin, 2003), and the congeneric status, and placement within Pterodactyloidea, of the two recognised Germanodactylus species (G. cristatus Plieninger, 1901 and G. rhamphastinus Wellnhofer, 1970) are also disputed (e.g. Maisch et al., 2004; Vidovic and Martill 2014). Irrespective of the outcome of these controversies, that Cuspicephalus has been likened to both pterodactyloids and basal monofenestratans validates the problems outlined above concerning to classifying fragmentary monofenestratans.

Considerations of a third potential non-pterodactyloid monofenestratan, MGCL 59'583, are similar to those of Cuspicephalus. MGCL 59'583 represents the holotype jaw tips of Normannognathus wellnhoferi Buffetaut et al., 1998, from the Upper Kimmeridgian Argiles d'Ecqueville, Normandy, France (Fig. 1B). This taxon has traditionally been likened to the pterodactyloid Germanodactylus (Buffetaut et al., 1998; Unwin, 2005) and sometimes considered part of the Germanodactylidae (Buffetaut et al., 1998; Unwin and Heinrich, 1999; Andres and Myers, 2013), a possibly paraphyletic (Unwin and Heinrich, 1999; Maisch et al., 2004) taxon comprising Normannognathus, Tendaguripterus recki Unwin and Heinrich, 1999, and Germanodactylus. However, Martill and Etches (2013) cast doubt on this identification, stating '[in] the light of the discovery of non-pterodactyloid monofenestratans, the holotype and only specimen of Normannognathus (MGCL 59'583) can no longer be placed in Germanodactylidae with confidence, and should be regarded as Monofenestrata indet.'(p. 292). 
Martill and Etches (2013) made no further elaboration on this point, but clear similarities between the crest morphology, jaw tips and dental alveoli of MGCL 59'583 and those of non-pterodactyloid monofenestratans are good cause for considering the affinities of Normannognathus open to question.

If Cuspicephalus and Normannognathus have affinities with germanodactylids, these pterosaurs represent some of the oldest pterodactyloid material known and certainly the oldest pterodactyloid crania (Fig. 2). If they represent wukongopterids or another form of non-pterodactyloid monofenestratan, they provide important new data on this poorly understood portion of pterosaur evolution. Because evidence presented for both possible identifications is either equivocal (Cuspicephalus) or in need of review (Normannognathus), we have attempted to resolve the phylogenetic placement of these poorly known taxa via detailed characterisation of nonpterodactyloid monofenestratan skulls. From this, we propose means to distinguish fragmentary skull mate- rial of early monofenestratan pterosaurs from those of early pterodactyloids, and apply our findings to Cuspicephalus and Normannognathus.

\section{Institutional abbreviations}

BSP, Bayerische Staatssammlung für Paläontologie und Geologie, Munich, Germany; HGM, Henan Geological Museum, China; GPIT, Paläontologische Forschungs, Lehrund Schausammlung, Institut für Geowissenschaften, Universität Tübingen, Tübingen, Germany; IVPP; Institute of Vertebrate Palaeontology and Palaeoanthropology, Beijing, China; MGCL, Musée Géologique Cantonal de Lausanne, France; MJML, Museum of Jurassic Marine Life (The Etches Collection), Kimmeridge, Dorset, UK; NHMUK, Natural History Museum, London, UK; NMING, National Museum of Ireland, Dublin, YH, Yizhou Museum, Yixian, Liaoning Province, China; ZMNH, Zhejiang Museum of Natural History, Hanzhou, Zhejiang Province, China.
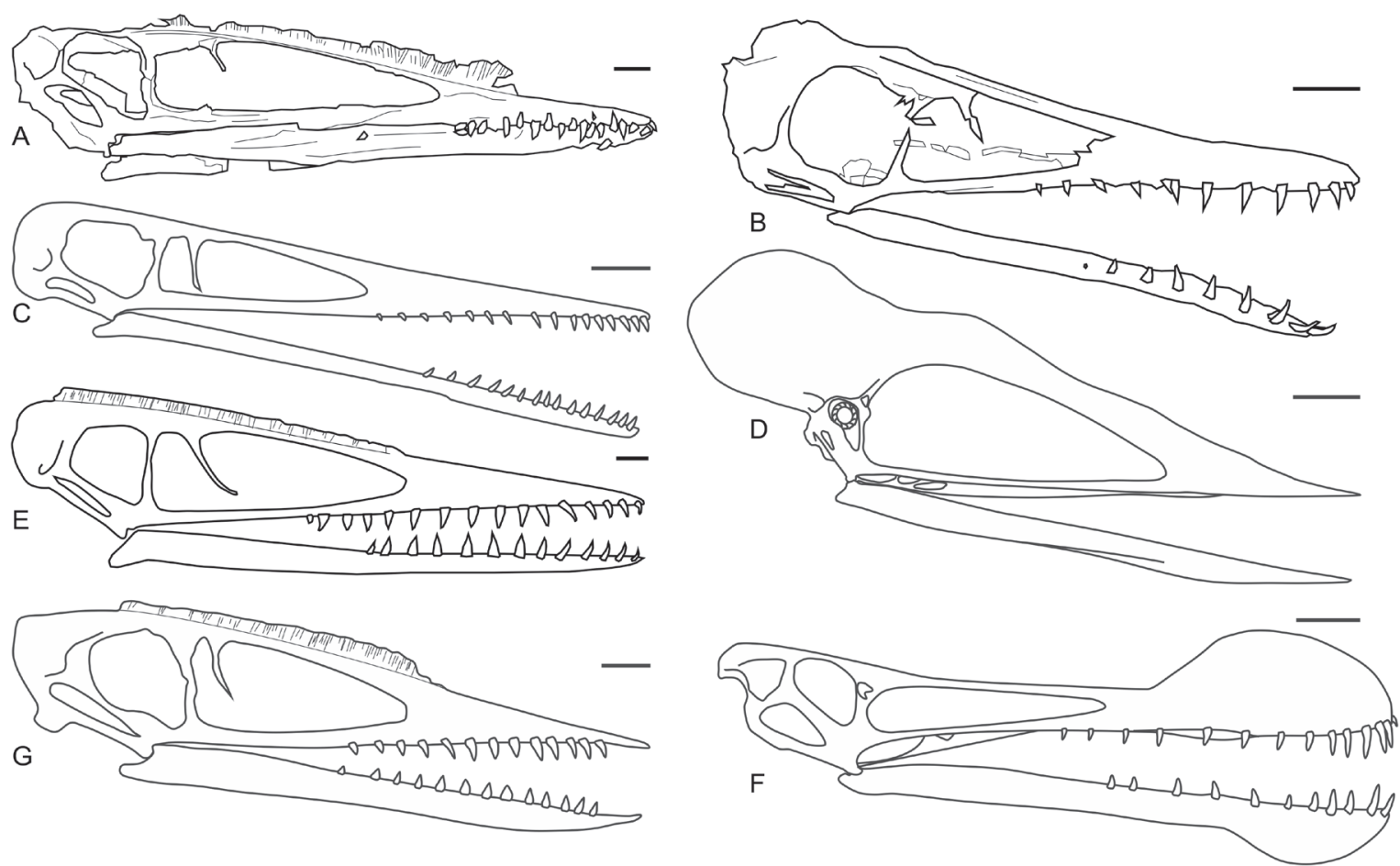

Fig. 3. Monofenestratan skulls. A, the wukongopterid Darwinopterus robustodens; B, likely pterodactyloid sister-taxon the 'Painten Pro-pterodactyloid'; C, ctenochasmatoid Pterodactylus antiquus; D, azhdarchoid Tupuxuara leonardii; E, early dsungaripteroid Germanodactylus rhamphastinus; F, ornithocheiroid Ornithocheirus mesembrinus; G, early dsungaripteroid Germanodactylus cristatus. Scale bars represent $10 \mathrm{~mm}$, except for D and F, which represent $100 \mathrm{~mm}$. A, after Lü et al., 2011a; B, after Tischlinger and Frey, 2014; C and E, after Wellnhofer, 1970; D and F, after Witton, 2013. 


\section{Material and methods}

\section{Systematic declaration}

Many aspects of pterosaur systematics remain contested. Key arguments include the relationships of major taxa, the diagnoses, names and content of many clades, methods to distinguish species and genera, and the number of valid species (e.g. Kellner, 2003, 2010; Unwin, 2003; Lü et al., 2010, 2011b; Andres and Meyers, 2013; Naish et al., 2013). The result is poor consensus on many components of pterosaur phylogeny, competing nomenclatural schemes with contradicting meanings for many established groups (e.g. compare Unwin, 2003; Kellner, 2003; Andres and Meyers, 2013) and multiple names for essentially identical clades (e.g. Novialoidea Kellner, 2003 vs. Breviquartossa Unwin, 2003). We are not the first authors to note these issues and the problems they create for modern pterosaur researchers (Naish et al., 2013; Geist et al., 2014): even basic discussion of pterosaur systematics now requires regular citation of the specific taxonomic scheme being followed (e.g. as in Andres and Meyers, 2013; Naish et al., 2013) or frequent mentions of conflicting interpretations (e.g. discussions in Witton, 2013). Pending resolution of these issues, and to ease readability, we follow other authors working in fields with controversial classifications by clearly stating the taxonomic scheme followed by the present article. Unless otherwise mentioned, we follow the nomenclature and taxonomy of Lü et al. (2010, 2012). Wang et al. (2010) and Andres et al. (2014) offer alternative schemes to those used here.

\section{Comparative anatomy}

Measurements and observation of the anatomy of Cuspicephalus scarfi MJML K1918 were made from the holotype specimen and data in Martill and Etches (2013), while measurements of Normannognathus wellnhoferi MGCL 59'583 were obtained from a highquality cast of the holotype and Buffetaut et al. (1998). Data on Tiaojishan wukongopterids and the 'Painten Pro-pterodactyloid' were obtained from literature (Lü et al., 2010, 2011a, b; Wang et al., 2009, 2010; Tischlinger and Frey, 2014). Data on Germanodactylus specimens and other Jurassic pterodactyloids were obtained from specimens, referred material (casts and original specimens), literature (e.g. Wellnhofer, 1970) and photographs.

\section{Results}

\section{Cranial characteristics of the Wukongopteridae}

Although undeniably pterodactyloid-like, the skulls of wukongopterids lack synapomorphies of most major pterodactyloid clades (Fig. 3; Kellner, 2003; Unwin, 2003; Andres and Ji, 2008). For example, they lack the rounded and reclined posterior skull regions of ctenochasmatoids, the depressed orbits and edentulous jaws of azhdarchoids, and the unusual rostral anatomy and dentition of ornithocheiroids (Kellner, 2003; Unwin, 2003; Andres and Ji, 2008). The wukongopterid skull most closely resembles those of early dsungaripteroids in overall skull proportions and shape, and particularly that of Germanodactylus rhamphastinus (Fig. 3E).

A number of similarities are present between wukongopterids and Germanodactylus. Both have striated cranial crests extending to the posterior region of the prenarial rostrum, generally with a gently sloping anterior margin. The crest of G. rhamphastinus differs here in terminating almost directly above the anterior margin of the nasoantorbital fenestra. This may reflect a genuine anatomical difference, but we are aware of the problems presented by poor preservation and historically erroneous preparation of pterosaur crests (Bennett, 2013a), as well as the current low number of G. rhamphastinus specimens (Bennett, 2006). The discovery of more specimens will clarify this morphology.

The anterior crests of wukongopterids and germanodactylids are relatively low compared to some pterosaurs. Each is lower than the height of the underlying prenarial rostrum, but the same crest portions of Cycnorhamphus and Dsungaripterus are as tall, if not taller, than the underlying rostrum (Young, 1973; Bennett, 2013b). The rostral indices (Martill and Naish, 2006) of sub-adult or older wukongopterids and Germanodactylus all plot within 3.04-5.07, with each group showing a wide range of values within this range (Martill and Etches, 2013). The preorbital skull length is rather short in G. cristatus (70\% of jaw tip to squamosal length), but the value for G. rhamphastinus (78\%) is very similar to those measured for wukongopterids (72-78\%). Wukongopterid and Germanodactylus tooth spacing is relatively uniform, with a slight increase in spacing posteriorly. Wukongopterid and Germanodactylus inter-alveoli spacing is generally larger than corresponding alveolus length, although this is less apparent for G. cristatus than for G. rhamphastinus. Teeth occur under the anterior half of the nasoantorbital fenestra along a relatively straight 
ventral skull margin in both wukongopterids and Germanodactylus.

In other respects wukongopterid crania differ markedly from skulls of both Germanodactylus species. Some distinctions concern characters which have previously suggested a close relationship between the Dsungaripteridae and Germanodactylus (Unwin, 2003), such as the expanded exoccipital processes of Germanodactylus cristatus (Unwin, 2003). This feature, unknown for any wukongopterid, is rarely discussed for Germanodactylus because it is poorly preserved in the holotype slab, BSP 1892 IV 1. However, a large exoccipital can clearly be seen in NMING:F15005, the counter-slab of the G. cristatus holotype (Fig. 4, also see Hone, 2010). It seems that expanded exoccipital processes are common to all dsungaripteroids (Unwin, 2003), although their presence in G. rhamphastinus cannot be evaluated because appropriate skull regions are not clearly preserved in any specimens we are aware of.

The orbits of wukongopterids are piriform, as they are in Germanodactylus and several other pterodactyloid lineages (see Lü et al., 2006 for a discussion of this character among the Pterodactyloidea). The anterodorsal region of their orbits are convex, this portion of their orbits being partially occupied by lacrimal and nasal bones. Orbits with similarly convex anterodorsal margins evolved repeatedly in pterosaurs, being present in rham-

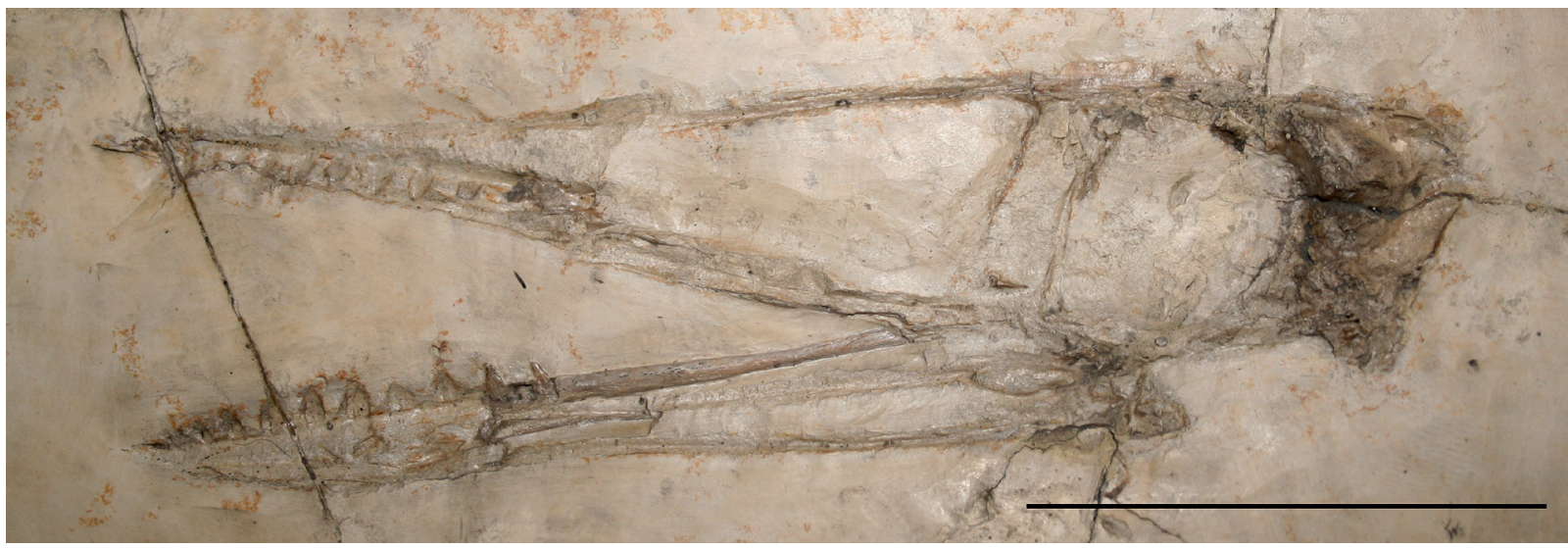

Fig. 4. Skull of NMING:F15005, Germanodactylus cristatus, holotype counter-slab, showing well-preserved expanded exoccipital process. This feature is vaguely discernible on the holotype, but much clearer on this slab. Scale bar represents $50 \mathrm{~mm}$. Photograph courtesy of David Hone.

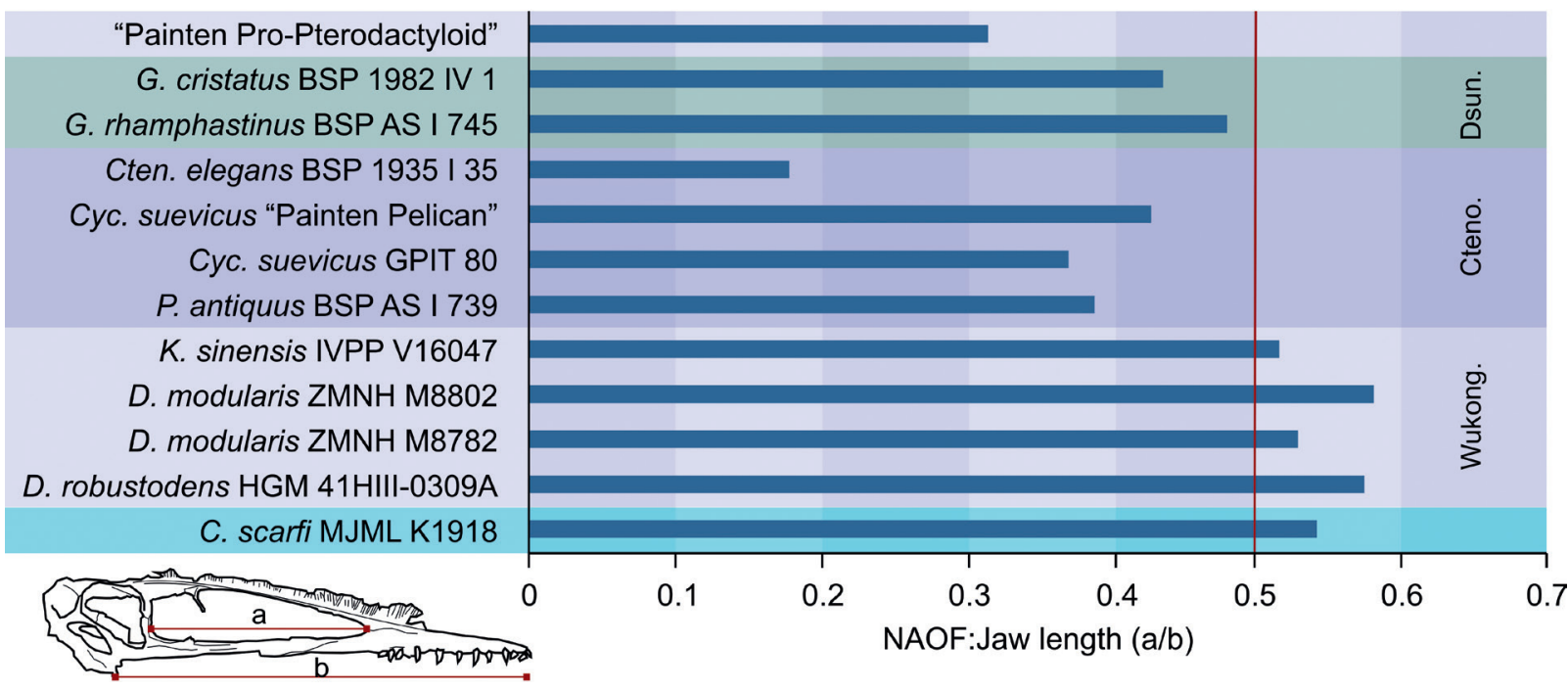

Fig. 5. Nasoantorbital fenestra length against jaw length in Late Jurassic monofenestratans. Cteno., Ctenochasmatoidea; Dsun., Dsungaripteroidea; Wukong., Wukongopteridae. 
phorhynchids, ctenochasmatoids, ornithocheirids and thalassodromids (e.g. Wellnhofer, 1970, 1975, 1987; Witton, 2013). They do not occur in either Germanodactylus species however. The nasal processes of many Jurassic monofenestratans are rather long (e.g. Germanodactylus, Cycnorhamphus, Pterodactylus; see Wellnhofer, 1970; Bennett, 2013b), but are relatively short in wukongopterids. Conversely, the anterior jugal process is suggested to be longer in some wukongopterids (e.g. D. linglongtaensis; Wukongopterus) than in Germanodactylus (e.g. Wang et al., 2009, 2010; Martill and Etches, 2013). Long anterior jugal processes may not be common to all wukongopterids however, being reportedly truncated in at least the holotype of $D$. modularis (Lü et al., 2010). We propose that this feature is variable within wukongopterids, or alternatively, that some interpretations of their jugal margins are erroneous. Cracks and marks interpreted as anterior margins of 'short' and 'long' jugal processes can be seen on many wukongopterid specimens, suggesting further investigation may be warranted to confirm their anterior jugal limits.

The nasoantorbital fenestra is longer with respect to jaw length in the Wukongopteridae than in other Jurassic monofenestratans (Fig. 5). Nasoantorbital openings are generally less than $40 \%$ of jaw length in ctenochasmatoids and the 'Painten pro-pterodactyloid', 43-48\% of the jaw length in Germanodactylus, but $51-58 \%$ of the jaw length in wukongopterids. Such a value places wukongopterid nasoantorbital openings amongst the longest of any monofenestratan, second only to istiodactylids and azhdarchoids (Kellner, 2003; Unwin, 2003; Witton, 2012). The dorsal margin of the wukongopterid preorbital rostrum, excluding the cranial crest, is concave, which contrasts with the straight dorsal margin of Germanodactylus rostra.

The expanded dentition of Germanodactylus is not mirrored in any wukongopterid. This is even the case in Darwinopterus robustodens, a species named for its relatively robust teeth (Lü et al., 2011a). Wukongopterids have a relatively slender, sharp, and pointed dentition generally similar to that of pterodactyloids like Pterodactylus and Haopterus (Wellnhofer, 1970; Wang and Lü, 2001). Wukongopterid teeth are also mostly evenly sized, whereas those of Germanodactylus expand markedly from the jaw tip with the broadest teeth at the midpoint of the toothrow (Wellnhofer, 1970). The larger teeth of wukongopterids are, like virtually all toothed pterosaurs, found towards the front of the jaw. Wukongopterid toothrows extend to the end of the jaws as they do in G. rhamphastinus and most non-dsun- garipteroid monofenestratans. Germanodactylus cristatus, however, has edentulous jaw tips.

The first premaxillary tooth pair arrangement in wukongopterids is distinctive. These alveoli are situated on the anteroventral margin of the jaw, a condition which sees the anterior teeth over-biting the lower jaw (Wang et al., 2009, 2010). This is somewhat reminiscent of the anterior dentition of ornithocheirids (e.g. Wellnhofer, 1987) and some ctenochasmatids (e.g. Howse and Milner, 1995), but the dentition and tooth arrangement of these pterosaurs is clearly demarked from wukongopterids and is very likely convergent. Wang et al. $(2009,2010)$ considered over-biting first premaxillary tooth pairs autapomorphic for Wukongopterus lii, but other wukongopterids demonstrate an identical condition (e.g. Lü et al., 2010; Wang et al., 2010). This feature is likely characteristic of the Wukongopteridae rather than a single wukongopterid genus.

Our assessment suggests that wukongopterid skulls can be distinguished from other Jurassic monofenestratans by not only lacking the well-documented cranial synapomorphies of pterodactyloid clades, but also through a unique combination of characters:

1. Striated bony crest lower than the underlying prenarial rostrum, with sloping anterior margin

2. Anterior crest terminates in the posterior region of the prenarial rostrum, closer to the anterior border of the nasoantorbital fenestra than the jaw tip

3. Reclined, but not sub-horizontal, occipital regions

4. Piriform orbit

5. Convex anterodorsal orbital margin

6. Short nasal process

7. Unexpanded exoccipital processes

8. Concave dorsal skull surface

9. Straight ventral skull surface

10. Nasoantorbital fenestra over $50 \%$ of jaw length

11. Small, equally sized alveoli

12. First alveolus pair located on anterior face of jaw, with mandible over-bitten by first premaxillary tooth pair

13. Regular tooth spacing

14. Interalveolar spacing generally greater than tooth length

15. Dentition extends under anterior half of the nasoantorbital region

16. Relatively slender, sharply pointed conical teeth

The particularly long nasoantorbital fenestra appears to be the most characteristic feature of wukongopterid skulls even though, as noted above, large nasoantorbital fenestrae are not unique to the Wukongopteridae within Monofenestrata. Among Jurassic pterosaurs 
however, wukongopterid nasoantorbital openings are the longest of any group, and only distantly related, derived Cretaceous pterodactyloids demonstrate a similar condition. This feature therefore provides a useful synapomorphy for Wukongopteridae.

\section{Cranial characteristics of the 'Painten pro-pterodacty- loid'}

Remarkably, the skull of the 'Painten pro-pterodactyloid' (Fig. 3B) bears several features considered characteristic of derived ctenochasmatoids, including a near-circular orbit, almost horizontal occipital region, and a rounded posterior skull (Kellner, 2003; Unwin, 2003; Tischlinger and Frey, 2014). The possession of these features in a taxon clearly demarked from the Pterodactyloidea by its postcrania is quite striking, and complicates our understanding of early pterodactyloid evolution. More pertinent to this study, they also allow for easy distinction of the crania of the 'Painten pro-pterodactyloid' from monofenestratan groups with mostly plesiomorphic skull anatomy, the wukongopterids and germanodactylids.

Within Ctenochasmatoidea, the skull of the 'Painten pro-pterodactyloid' is most similar to that of Pterodactylus (Fig. 3C). This occurs through its short nasoantorbital fenestra (Fig. 5), straight ventral skull margin, convex anterodorsal orbital margin, long nasal process, relatively short, pointed teeth and (as seen in juvenile Pterodactylus) concave dorsal skull margin. They are primarily differentiated by the very wide spacing and reduced number of teeth of the Painten specimen, as well as its procumbent anterior mandibular dentition (Tischlinger and Frey, 2014). The anterior premaxillary teeth, by contrast, are not procumbent. The regular alveolar spacing of the 'Painten pro-pterodactyloid' is a further distinguishing feature, contrasting with the posteriorly-increasing alveolus spacing of Pterodactylus and other Late Jurassic monofenestratans. The heavier construction of the prenarial rostrum and proportionally shorter, taller skull are also characteristic for the Painten specimen, but these features vary with ontogeny (e.g. Bennett, 1995, 2006, 2013a) and their taxonomic significance is questionable. Likewise, the absence of a striated crest in the Painten specimen might be a useful identifying feature given the propensity of crests in ctenochasmatoids (e.g. Wellnhofer, 1970; Dong, 1980; Bennett, 2013a), but could also reflect ontogenetic or individual variation (Lü et al. 2011b). Studies into the ontogenetic status of the 'Painten pro-pterodactyloid' will hopefully provide some insights into the diagnostic utility of these characters (see Bennett, 1993).
Thus the 'Painten pro-pterodactyloid' can be distinguished from other Jurassic monofenestratans by a combination of 13 character states:

1. Near-horizontal occipital region

2. Rounded posterior skull

3. Sub-circular orbit

4. Convex anterodorsal orbital margin

5. Concave dorsal skull surface

6. Straight ventral skull surface

7. Robust prenarial rostrum

8. Interalveolar spacing much greater than alveolus lengths

9. Consistent alveolus spacing

10. Dentition extends under anterior half of the nasoantorbital region

11. No anteriorly-facing premaxillary teeth at jaw tip

12. Relatively slender, sharply pointed conical teeth

13. Procumbent first and second pairs of mandibular teeth

Most of these characters are not diagnostic in isolation. However, some features of the dentition seem apomorphic. The combination of procumbent anterior mandibular teeth with vertical anterior premaxillary teeth is unique, as is the arrangement of the mandibular dentition, where only the anteriormost two tooth pairs are procumbent, while the remaining teeth are vertical.

\section{Discussion}

\section{Cuspicephalus scarfi}

Twelve of the 16 wukongopterid features listed above can be evaluated on the holotype of Cuspicephalus scarfi. Virtually all of them meet the conditions seen in wukongopterid skulls. These include a low striated crest terminating above the posterior region of the prenarial rostrum; reclined posterior skull face; piriform orbit; a nasoantorbital fenestra exceeding 50\% of the jaw length (at least 54\%; Fig 5); small, relatively uniformly-sized alveoli, and a toothrow terminating under the anterior end of the nasoantorbital fenestra. The dorsal margin of the rostrum is not entirely preserved, but it can be reconstructed as gently concave with fair confidence (Martill and Etches, 2013), and the ventral skull margin is straight. The exoccipital processes are unexpanded: they look relatively large on MJML K1918, but this is largely an artefact of distortion around the occipital region, and they are not as prominent as those of Germanodactylus or dsungaripterids. Only one feature of MJML K1918 is inconsistent with a wukongopterid 
identification: the anterior alveoli of MJML K1918 are separated by less than one alveolus-length, although the spacing of the posterior alveoli is more typical of the wukongopterid condition. The status of the anterodorsal region of the orbit, the presence of anteriorly-facing premaxillary alveoli and the length of the nasal process cannot be confidently determined for MJML K1918. Martill and Etches (2013) indicated that the nasal process may be represented by a small, faint trace in MJML K1918, but its length cannot be accurately assessed. Nevertheless, we conclude that 11 of the 12 observable or inferable characters of Cuspicephalus resemble a wukongopterid-like skull configuration and only one, alveolus spacing, shows a slightly different state.

In contrast, Cuspicephalus does not possess characters clearly indicative of close relationships to other monofenestratan taxa, including the 'Painten Pro-pterodactyloid' and Germanodactylidae. MJML K1918 can be evaluated for nine characters provided here for the 'Painten Pro-pterodactyloid' skull but is congruous with only three (concave dorsal rostrum; straight ventral skull; dentition under nasoantorbital fenestra). Similarly, Cuspicephalus differs from Germanodactylus in lacking a straight dorsal rostral margin and expanded exoccipital processes. Based on alveolus size, it also possessed more gracile teeth which increased in size anteriorly, not medially as in Germanodactylus. Martill and Etches (2013) argued that the shortness of the anterior jugal process suggested affinities with Germanodactylus but, as noted above, long anterior jugal processes may not be ubiquitous across the Wukongopteridae.

The Cuspicephalus skull meets nearly all character conditions of wukongopterid pterosaurs, but lacks many defining characteristics of other Jurassic pterosaurs, supporting the suggested close relationship with Darwinopterus (Martill and Etches, 2013) and indicating placement elsewhere among the Monofenestrata is unlikely. Furthermore, its possession of a feature unseen in Jurassic pterosaurs outside of wukongopterids - the especially elongate nasoantorbital fenestra - strongly suggests placement within Wukongopteridae. The differences it has with other wukongopterids - a proportionally long skull, higher tooth count and more condensed alveolus spacing at the jaw tip (Martill and Etches, 2013) - are not problematic for this identification: variable rostrum length and dental counts are typical within pterosaur clades. Indeed, greater rostrum length and tooth counts may be expected for a pterosaur of larger absolute size than its close relatives (see below). We thus consider a wukongopterid placement most likely for Cuspicephalus: the significance of this is discussed below.

\section{Normannognathus wellnhoferi}

In being represented by less material than Cuspicephalus, Normannognathus presents a much greater challenge for identification. Normannognathus can only be fully evaluated for nine of the features identified in our list of wukongopterid characteristics, with five positive comparisons. It can be compared with six characteristics of the 'Painten Pro-pterodactyloid', but none compare favourably.

Normannognathus bears a striated crest extending beyond the nasoantorbital region and terminating with an overturned leading edge. This crest is proportionally very tall - perhaps the tallest of any pterosaur when compared to the underlying rostrum height. We agree with Buffetaut et al. (1998) that the crest shape of Normannognathus is more reminiscent of Dsungaripterus than any other pterosaur, and it certainly differs from the condition in Germanodactylus, wukongopterids and the crestless 'Painten Pro-pterodactyloid' specimen. Only the ctenochasmatoid Huanhepterus quingyangensis offers a crest of similar height when compared to underlying rostral proportions (Dong, 1982). The proximity of the Normannognathus anterior crest margin to the nasoantorbital fenestra cannot be evaluated, nor is it clear from the dorsal and ventral rostral margins how the skull shape continued beyond the broken jaw tips. We see no reason to infer a short, Germanodactylus-like skull for Normannognathus any more than a much longer, lower skull akin to that of the ctenochasmatoids Feilongus (Wang et al., 2005) or Huanhepterus. MGCL 59 '583 possesses a low, concave dorsal rostral margin but also a convex ventral surface, together forming an upturned jaw tip. The upturned jaw of MGCL 59'583 is genuine, but the specimen is slightly distorted and obliquely preserved, so this feature is not as pronounced as it may first appear (Buffetaut et al., 1998). Upturned jaws are known from Pteranodon, ctenochasmatoid, dsungaripterid and istiodactylid pterodactyloids (e.g. Young, 1973; Bennett, 1996, 2001; Wang et al., 2005; Witton, 2012), but are not apparent in either wukongopterids or the 'Painten Pro-pterodactyloid'. The rostrum of Normannognathus is rather more slender than that of the 'Painten Pro-pterodactyloid'.

Some aspects of the MGCL 59'583 alveoli match the wukongopterid condition, being of approximately uniform size with the anterior pair situated on the anteroventral surface of the premaxilla. The spacing of the alveoli is generally tighter than those of wukongopterids however, surpassing even the spacing frequency of $\mathrm{Cus}$ picephalus. A solitary tooth is preserved in the mandible 
Table 1. Skull and wing bone lengths ( $\mathrm{mm}$ ) of complete wukongopterids from the Tiaojishan Formation, used in wingspan estimation of MJML K1918. McIV, metacarpal IV.

\begin{tabular}{|c|c|c|c|c|c|c|c|c|c|c|}
\hline \multirow[b]{2}{*}{ Taxon } & \multirow[b]{2}{*}{ Specimen } & \multirow[b]{2}{*}{ Skull } & \multirow[b]{2}{*}{ Hum } & \multirow[b]{2}{*}{$\mathrm{Ul}$} & \multirow[b]{2}{*}{ McIV } & \multicolumn{4}{|c|}{ Wing finger phalanges } & \multirow[b]{2}{*}{ Wingspan } \\
\hline & & & & & & I & II & III & IV & \\
\hline Darwinopterus linlongtaensis & IVPP V16049 & 119.2 & 40.4 & 58 & 23.6 & 46.2 & 50.7 & 53.2 & 53.6 & 651.4 \\
\hline Kunpengopterus sinensis & IVPP V16047 & 106.9 & 36.2 & 59.2 & 23 & 54.2 & 58 & 59.2 & 48.8 & 677.2 \\
\hline Darwinopterus robustodens & HGM 41HIII-0309A & 175 & 50 & 80 & 30 & 65 & 75 & 75 & 67 & 884 \\
\hline Darwinopterus modularis & YH-2000 & 140 & 44 & 64 & 26 & 48 & 55 & 59 & 53 & 698 \\
\hline
\end{tabular}

of MGCL 59'583 but does not taper to a sharp point like the teeth of wukongopterids. Rather, it is relatively long and slender, more akin to the teeth of ctenochasmatids and certainly very different to the robust dentition seen in Germanodactylus and Tendaguripterus. This tooth projects anterolaterally from the alveolus in a ctenochasmatid manner, although additional discoveries are probably required to verify this as the in vivo condition and not post-mortem displacement. The alveolar spacing, positions and apparent dental orientations contrast markedly with the distinctive dentition of the 'Painten Propterodactyloid'.

Further features of interest in MGCL 59'583 are the midline grooves on the occlusal surfaces of the upper jaw and mandibular symphysis. The symphyseal trough is wider and deeper than the groove of the upper jaw, which is relatively shallow and only clearly seen at the jaw tip. Among toothed pterosaurs, midline jaw grooves are well documented in ornithocheirids and lonchodectids (e.g. Unwin, 2001), but are poorly known in other groups. For Jurassic monofenestratans at least, this reflects the frequent lateral crushing of pterosaur skulls. Nevertheless, the germanodactylid Tendaguripterus lacks a mandibular groove (Unwin and Heinrich, 1999), as do dsungaripterids (e.g. Young et al., 1973). The Jurassic ctenochasmatoid Gnathosaurus macrurus bears a symphyseal trough (Howse and Milner, 1995). The status of jaw grooves in wukongopterids and the 'Painten Pro-pterodactyloid' remains unknown.

Normannognathus possesses a mosaic of monofenestratan features with conflicting phylogenetic signals, preventing confident referral to any specific monofestratan clade, including the Germanodactylidae. Buffetaut et al. (1998) referred Normannognathus to this group because of its crest morphology, similar tooth distribution to G. rhamphastinus and the possible close relationship of Germanodactylus to Dsungaripterus, which Normannognathus resembles by its upturned jaw and crest size. However, these features are now recognised as widely distributed across the Monofenestrata, and no

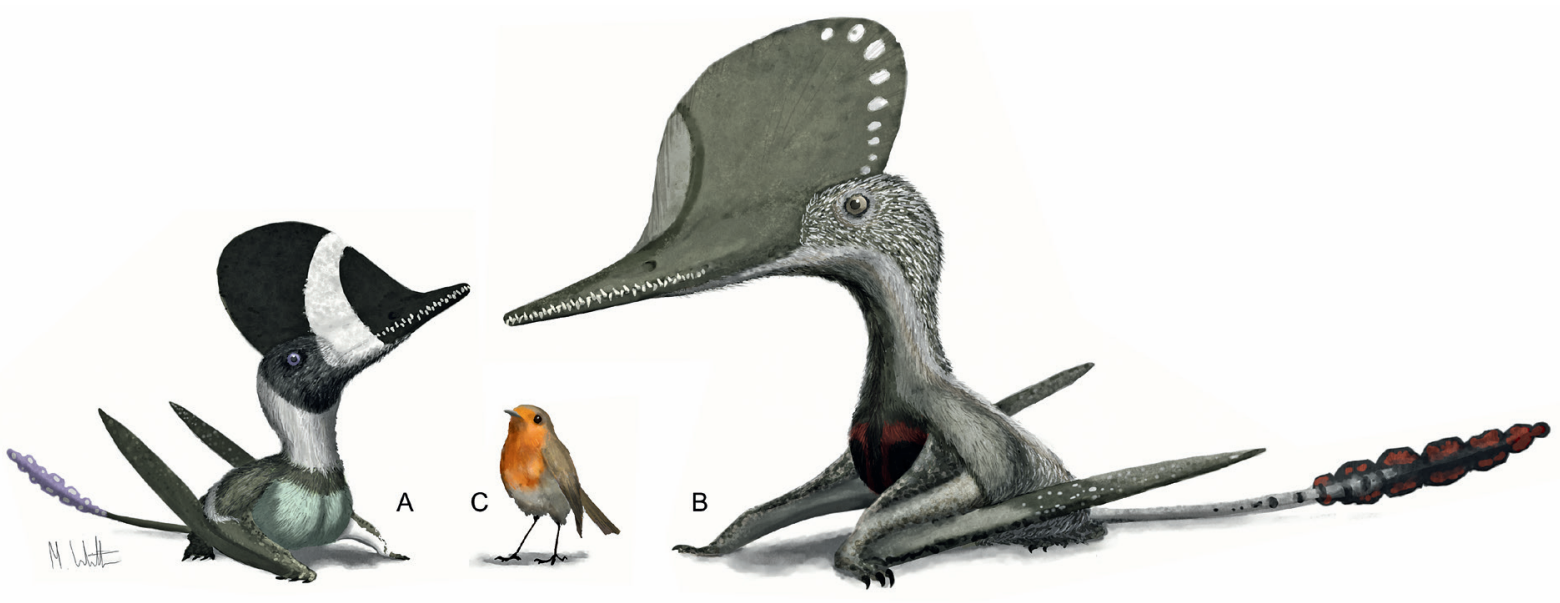

Fig. 6. Life reconstructions of wukongopterid pterosaurs showing size range across the group with extant avian for scale. A, Darwinopterus robustodens, the largest Tiaojishan Formation wukongopterid with a $884 \mathrm{~mm}$ wingspan; B, Cuspicephalus scarfi, with a projected wingspan of $1.2 \mathrm{~m}$; C, European robin, Erithacus rubecula (wingspan c., $200 \mathrm{~mm}$ ). 
longer exclusively indicate a close relationship with Germanodactylus. Indeed, we do not find any features on MGCL 59'583 which unambiguously indicate germanodactylid affinities and, to the contrary, find much of its anatomy inconsistent with this placement.

What Normannognathus represents remains difficult to ascertain, however. It remains a valid genus due to its unique assemblage of characters, but placing it within an existing pterosaur group is problematic. It differs from wukongopterids as much as it resembles them, bears no features of the 'Painten Pro-pterodactyloid' or clear synapomorphies of any major pterodactyloid clade. The constituent components of Normannognathus anatomy - steeply terminating, relatively tall striated crests; slightly upturned, shallow rostra with slender, anteriorly directed teeth and symphyseal troughs - occur in several ctenochasmatoids including Huanhepterus (Dong, 1982); Cycnorhamphus suevicus (Bennett, 2013a), Aurorazhdarcho micronyx (Bennett, 2013b), Feilongus youngi (Wang et al., 2005) and Gnathosaurus macrurus (Howse and Milner, 1995). Normannognathus may therefore have affinities with the Ctenochasmatoidea, but more complete remains are required to make a confident assessment of its systematic position. At present it may be best considered Monofenestrata incertae sedis.

Significance of Cuspicephalus scarfi interpreted as a wukongopterid

The suggestion that wukongopterid skulls can be distinguished from those of other early monofenestratans without associated postcranial material bodes well for further research into this group. However, their low number of cranial synapomorphies proves limiting when considering particularly fragmentary monofenestratan crania, as evidenced by difficulties resolving the affinities of Normannognathus. We hope the comparisons made here will be useful in future assessments of Jurassic monofenestratan material, such as the fragmentary crania from the Purbeck Limestone, Kimmeridge Clay and Morrison formations.

The occurrence of a wukongopterid in Kimmeridgian deposits of the southern UK expands the stratigraphic and geographic range of this group significantly. Presently, all wukongopterids are known from the upper Oxfordian or Lower Callovian Tiaojishan Formation of northeast China. Cuspicephalus scarfi extends the wukongopterid stratigraphic range into the Kimmeridgian, being the youngest wukongopterid by at least 5 million years, and expands the geographic range of the group to
Europe. This makes wukongopterid palaeobiogeography comparable to that of other Middle and Late Jurassic pterosaur lineages, most of which are distributed across multiple continents or even cosmopolitan in their distribution (see Barrett et al., 2008 and Witton, 2013 for recent overviews of pterosaur palaeobiogeography).

Cuspicephalus further offers new insights into wukongopterid disparity. It is the first wukongopterid to obviously differ from the Darwinopterus-like taxa of the Tiaojishan Formation, animals which are so morphologically similar that Lü et al. (2011b) suggest they represent a single taxon. The skull of Cuspicephalus is proportionally longer and lower than any Tiaojishan form, its teeth more numerous and tightly packed at the jaw tip. This presumably reflects ecological differentiation from the Chinese wukongopterids, perhaps allowing for greater reach during foraging and manipulating relatively small or slippery prey. Moreover, Cuspicephalus is also considerably larger than its relatives. At $326 \mathrm{~mm}$ long, the skull of Cuspicephalus is much longer than those of its fellow wukongopterids and also one of the largest Jurassic pterosaur skulls known. Only the Morrison Formation scaphognathine Harpactognathus gentryii is estimated to have a skull of comparable length (280-300 mm; Carpenter et al., 2003). By contrast, the largest Tiaojishan wukongopterid skull (HGM 41HIII-0309A; the osteologically mature holotype of Darwinopterus robustodens) is $175 \mathrm{~mm}$ long (Fig. 3A), $53 \%$ of the skull length of Cuspicephalus. A regression of skull length against wingspan of complete Tiaojishan wukongopterids (Table 1) shows that their skull length scales with negative allometry to wingspan $\left(n=4, r^{2}=\right.$ 0.7997), predicting a wing spread of $1.2 \mathrm{~m}$ for Cuspicephalus. This is $35 \%$ greater than the $884 \mathrm{~mm}$ estimated for D. robustodens (Fig. 6) and, while smaller than the predicted 1.8-2.5 m wingspans of the largest Jurassic pterosaurs, such as Harpactognathus and Rhamphorhynchus, still brings wukongopterids into a new size class of pterosaurs.

\section{Acknowledgements}

We thank Sandra Chapman and Lorna Steel for access to NHMUK specimens, and Steve Etches for access to specimens in his care. Stephen Vidovic and David Hone are thanked for kindly providing photographs of $G$. rhamphastinus and the $G$. cristatus counter-slab. Chris Bennett and an anonymous referee are thanked for constructive comments provided in peer review. DMM thanks David Unwin for making images available of Darwinopterus available before their publication and Helmut Tischlinger for discussions on the 'Painten Pro-pterodactyloid" 


\section{References}

Andres B, Ji Q. 2008. A new pterosaur from the Liaoning Province of China, the phylogeny of the Pterodactyloidea, and the convergence in their cervical vertebrae. Palaeontology 51: 453-469.

Andres B, Myers TS. 2013. Lone Star Pterosaurs. Earth and Environmental Science Transactions of the Royal Society of Edinburgh 103: 383-398.

Andres B, Howard L, Steel L. 2011a. Owen's pterosaurs, old fossils shedding light on new clades. P. 4 in: Forrest R, ed., SVPCA, 59th Annual Symposium of Vertebrate Palaeontology and Comparative Anatomy, Abstracts of Presentations.

Andres B, Howard L, Steel L. 2011b, Pterosaurs, modules, and the origin of the Pterodactyloidea. Journal of Vertebrate Paleontology 31(A): 62.Andres B, Clark J, Xu X. 2014. The earliest pterodactyloid and the origin of the group. Current Biology 24: 1011-1016.

Barrett PM, Butler RJ, Edwards NP, Milner AR. 2008. Pterosaur distribution in space and time: an atlas. Zitteliana B28: 61-107.

Bennett SC. 1993. The ontogeny of Pteranodon and other pterosaurs. Paleobiology 19: 92-106.

Bennett SC. 1995. A statistical study of Rhamphorhynchus from the Solnhofen Limestone of Germany: year-classes of a single large species. Journal of Paleontology 16: 569-580.

Bennett SC. 1996. Year-classes of pterosaurs from the Solnhofen Limestone of Germany: taxonomic and systematic implications. Journal of Vertebrate Paleontology 16: 432-444.

Bennett SC. 2001. The osteology and functional morphology of the Late Cretaceous pterosaur Pteranodon. Palaeontographica Abteilung A 260: 1-153.

Bennett SC. 2006. Juvenile specimens of the pterosaur Germanodactylus cristatus, with a review of the genus. Journal of Vertebrate Paleontology 26: 872-878.

Bennett SC. 2013a. New information on body size and cranial display structures of Pterodactylus antiquus, with a revision of the genus. Paläontologische Zeitschrift 87: 269-289.

Bennett SC. 2013b. The morphology and taxonomy of the pterosaur Cycnorhamphus. Neues Jahrbuch für Geologie und Paläontologie-Abhandlungen 267: 23-41.

Buffetaut E, Lepage J, Lepage G. 1998. A new pterodactyloid from the Kimmeridgian of the Cape de la Héve (Normandy, France). Geological Magazine 135: 719-722.

Carpenter K, Unwin DM, Cloward K, Miles C, Miles C. 2003. A new scaphognathine from the upper Jurassic Morrison Formation of Wyoming, USA. Pp. 45-54 in: Buffetaut E, Mazin JM, eds, Evolution and Palaeobiology of Pterosaurs, Geological Society Special Publication 217.

Dong Z. 1982. A new pterosaur (Huanhepterus quingyangensis gen. et sp. nov.) from Ordos, China. Vertebrata PalAsiatica 20: $115-121$.

Geist NR, Hillenius WJ, Frey E, Jones TD, Elgin RA. 2014. Breathing in a box: Constraints on lung ventilation in giant pterosaurs. The Anatomical Record 297: 2233-2253.

Hone DW. 2010. A short note on modifications to nineteenth century pterosaur specimens held in the National Museum of Ireland-Natural History, Dublin. Geological Curator 9: 261265.

Hone DW. 2012. Pterosaur research: recent advances and a future revolution. Acta Geologica Sinica-English Edition 86: 1366 1376.
Howse SCB, Milner AR. 1995. The pterodactyloids from the Purbeck Limestone Formation of Dorset. Bulletin of the Natural History Museum, London 51: 73-88.

Kellner AWA. 2003. Pterosaur phylogeny and comments on the evolutionary history of the group. Pp. 105-137 in: Buffetaut E, Mazin JM, eds, Evolution and Palaeobiology of Pterosaurs, Geological Society Special Publication 217.

Kellner AWA. 2010. Comments on the Pteranodontidae (Pterosauria, Pterodactyloidea) with the description of two new species. Anais da Academia Brasileira de Ciências 82: 1063 1084.

Lü JC. 2009. A new non-pterodactyloid pterosaur from Qinglong County, Hebei Province of China. Acta Geologica Sinica 83: 189-199.

Lü JC, Fucha X. 2010. A new pterosaur (Pterosauria) from the Middle Jurassic Tiaojishan Formation of western Liaoning, China. Global Geology 13: 113-118.

Lü JC, Jin X, Unwin DM, Zhao L, Azuma Y, Ji Q. 2006. A new species of Huaxiapterus (Pterosauria: Pterodactyloidea) from the Lower Cretaceous of Western Liaoning, China with comments on the systematics of tapejarid pterosaurs. Acta Geologica Sinica 80: 315-326.

Lü JC, Unwin DM, Jin X, Liu Y, Ji Q. 2010. Evidence for modular evolution in a long-tailed pterosaur with a pterodactyloid skull. Proceedings of the Royal Society B 277: 383-389.

Lü JC, Xu L, Chang H, Zhang X. 2011a. A new darwinopterid pterosaur from the Middle Jurassic of Western Liaoning, Northeastern China and its ecological implications. Acta Geologica Sinica 85: 507-514.

Lü, JC, Unwin DM, Deeming DC, Jin X, Liu Y, Ji, Q. 2011b. An egg-adult association, gender, and reproduction in pterosaurs. Science 331: 321-324.

Lü JC, Unwin DM, Zhou B, Chunling G, Shen C. 2012. A new rhamphorhynchid (Pterosauria: Rhamphorhynchidae) from the Middle/Upper Jurassic of Qinglong, Hebei Province, China. Zootaxa 3158: 1-19.

Maisch MW, Matzke AT, Sun G. 2004. A new dsungaripteroid pterosaur from the Lower Cretaceous of the southern Junggar Basin, north-west China. Cretaceous Research 25: 625-634.

Martill DM, Naish D. 2006. Cranial crest development in the azhdarchoid pterosaur Tuрихиаra, with a review of the genus and tapejarid monophyly. Palaeontology 49: 925-941.

Martill DM, Etches S. 2013. A monofenestratan pterosaur from the Kimmeridge Clay Formation (Upper Jurassic, Kimmeridgian) of Dorset, England. Acta Palaeontologica Polonica 58: 285-294.

Naish D, Simpson M, Dyke G. 2013. A new small-bodied azhdarchoid pterosaur from the Lower Cretaceous of England and its implications for pterosaur anatomy, diversity and phylogeny. PloS one 8: e58451.

Plieninger F. 1901. Beiträge zur Kenntnis der Flugsaurier. Palaeontographica 48: 65-90.

Steel L. 2010. The pterosaur collection at the Natural History Museum, London, UK: history, overview, recent curatorial developments and exciting new finds. Acta Geoscientica Sinica 31: 59-61.

Sullivan C, Wang Y, Hone DWE, Wang YQ, Xu X, Zhang F. 2014. The vertebrates of the Jurassic Daohugou Biota of Northeastern China. Journal of Vertebrate Paleontology 34: 243-280.

Tischlinger H, Frey E. 2014. Ein neuer Pterosaurier mit Mosaikmerkmalen basaler und pterodactyoider Pterosaurier aus dem 
Ober-Kimmeridgium von Painen (Oberpfalz, Deutschland) [A new pterosaur with moasic characters of basal and pterodactyloid Pterosauria from the Upper Kimmeridgian of Painten (Upper Palatinate, Germany)]. Archaeopteryx 31: 1-13.

Unwin DM. 1996. The fossil record of Middle Jurassic Pterosaurs. Pp. 291-304 in: Morales M, ed., The Continental Jurassic, Museum of Northern Arizona Bulletin 60.

Unwin DM. 2001. An overview of the pterosaur assemblage from the Cambridge Greensand (Cretaceous) of Eastern England. Mitteilungen Museum für Naturkunde Berlin, Geowissenschaftlichen 4: 189-221.

Unwin DM. 2003. On the phylogeny and evolutionary history of pterosaurs. Pp. 139-190 in: Buffetaut E, Mazin JM, eds, Evolution and Palaeobiology of Pterosaurs, Geological Society Special Publication, 217.

Unwin DM. 2005. The Pterosaurs from Deep Time. Pi Press, New York.

Unwin DM, Heinrich WD. 1999. On a pterosaur jaw from the Upper Jurassic of Tendaguru (Tanzania). Mitteilungen aus dem Museum Für Naturkunde in Berlin Geowissenschaftliche Reihe 2: 121-134.

Vidovic SU, Martill DM. 2014. Pterodactylus scolopaciceps Meyer, 1860 (Pterosauria, Pterodactyloidea) from the Upper Jurassic of Bavaria, Germany: the problem of cryptic pterosaur taxa in early ontogeny. PloS one 9: e110646.

Wang X, Lü JC. 2001. Discovery of a pterodactylid pterosaur from the Yixian Formation of western Liaoning, China. Chinese Science Bulletin 46: 1112-1117.

Wang X, Kellner AWA, Zhou Z, Campos DA. 2005. Pterosaur diversity and faunal turnover in Cretaceous terrestrial ecosystems in China. Nature 437: 875-879.
Wang X, Kellner AWA, Jiang S, Meng X. 2009. An unusual longtailed pterosaur with elongated neck from western Liaoning of China. Anais da Academia Brasileira de Ciências 81: 793-812.

Wang X, Kellner AWA, Jiang S, Cheng X, Meng X, Rodrigues T. 2010. New long-tailed pterosaurs (Wukongopteridae) from western Liaoning, China. Anais da Academia Brasileira de Ciências 82: 1045-1062.

Wellnhofer P. 1970. Die Pterodactyloidea (Pterosauria) der Oberjura-Plattenkalke Süddeutschlands. Bayerische Akademie der Wissenschaften, Mathematisch-Wissenschaftlichen Klasse, Abhandlugen 141: 1-133.

Wellnhofer P. 1975. Die Rhamphorhynchoidea (Pterosauria) der Oberjura-Plattenkalke Süddeutschlands. Palaeontographica A 148: 1-33, 132-186, 149: 1-30.

Wellnhofer P. 1987. New crested pterosaurs from the Lower Cretaceous of Brazil. Mitteilungen der Bayerischen Staatsammlung für Paläontologie und Historische Geologie 27: 175-186.Witton MP. 2012. New insights into the skull of $I s$ tiodactylus latidens (Ornithocheiroidea, Pterodactyloidea). PLoS ONE 7: e33170.

Witton MP. 2013. Pterosaurs: Natural History, Evolution, Anatomy. Princeton University Press.

Young CC. 1973. Pterosaurian fauna from Wuerho, Sinkiang. Pp. 18-34 in: Reports of paleontological expedition to Sinkiang II, Kexue Chubanshe, Nanjing, China.

Received: 2 July 2014

Revised and accepted: 22 January 2015

Published online: 8 May 2015

Editor: M. Laurin 